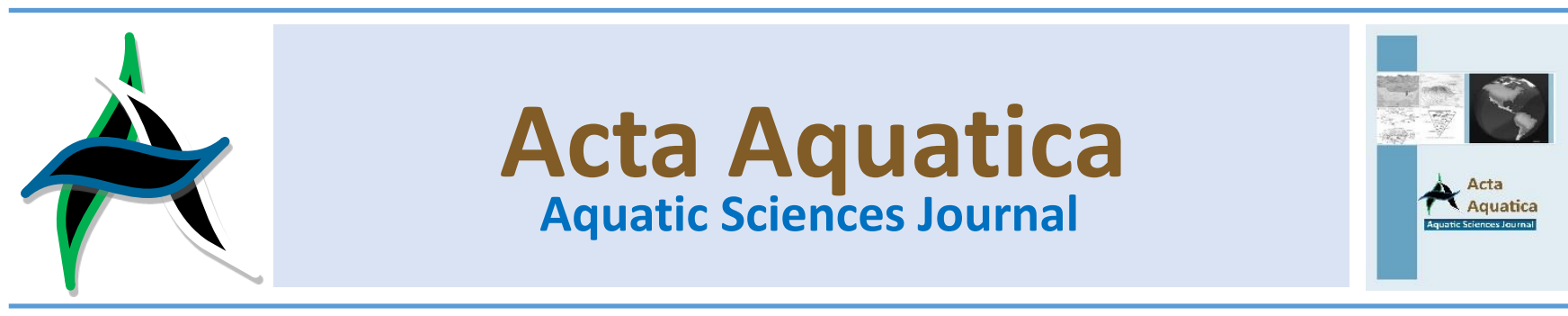

\title{
Penambahan ekstrak larutan kulit mangrove pada cat minyak sebagai antifouling
}

\section{The introduction of mangrove bark extracts to oil paint as an antifouling solution}

\author{
Fauzi Syahputra ${ }^{a, *}$ dan Teuku Muhammad Haja Almuqaramah ${ }^{\text {b }}$ \\ a Program Studi Pemanfaatan Sumberdaya Perikanan, Fakultas Perikanan, Universitas Abulyatama, Indonesia \\ ${ }^{b}$ Program Studi Budidaya Perairan, Fakultas Perikanan, Universitas Abulyatama, Indonesia
}

\begin{abstract}
Abstrak
Biofouling merupakan akumulasi pertumbuhan dari organisme laut yang hidupnya menempel pada material terendam oleh air laut. Akumulasi biofouling yang terjadi secara berkelanjutan dapat menimbulkan masalah baik secara ekonomis dan operasional khususnya pada kapal yang digunakan sebagai alat transportasi. hal ini dapat menyebabkan kecepatan kapal berkurang hingga 40\% sehingga konsumsi bahan bakar meningkat sampai dengan $30 \%$. Penelitian ini bertujuan mengetahui pengaruh penambahan ekstrak larutan kulit mangrove pada cat minyak sebagai antifouling. Hasil penelitian menunjukan bahwa penambahan ekstrak larutan kulit mangrove memiliki pengaruh terhadap jumlah penempelan biofouling. Hal ini dapat dilihat dari data yang didapatkan dimana pada material bahan uji yang menggunakan campuran tanin lebih sedikit terjadi penempelan pada material yaitu sebanyak 4 individu, sedangkan jika dibandingkan dengan sampel uji yang tidak menggunakan campuran tanin jumlah yang terdata sebanyak 9 individu.
\end{abstract}

\begin{abstract}
Biofouling is the accumulation of marine organisms whose life is attached to material submerged by sea water. Accumulation of biofouling that occurs on an ongoing basis can cause problems both economically and operationally, especially on ships that used as a means of transportation. This particular problem can cause ship speed to decrease by $40 \%$ so that fuel consumption increases by up to $30 \%$. This study aims to determine the effect of adding extracts of mangrove bark solution to oil paint as antifouling. The results showed that the addition of mangrove bark solution extract influenced the amount of biofouling attachment. Where in the test material using a mixture of tannins, there was less attachment to the material as much as four individuals, whereas when compared with the test sample which did not use a mixture of tannins the amount recorded was nine individuals.
\end{abstract}

Keywords: biofauling; antifauling; mangrove

\footnotetext{
* Korespondensi: Program Studi Pengelolaan Sumberdaya Perikanan Fakultas Perikanan, Universitas Abulyatama. Jl. Blang Bintang Lama Km 8,5, Lampoh Keudee, Aceh Besar, 23272 Provinsi Aceh, Indonesia. Tel: +62-651-21255.

e-mail:fauzi_psp@abulyatama.ac.id

doi: https://doi.org/10.29103/aa.v6i1.1062
}

\section{Pendahuluan}

Biofouling merupakan akumulasi pertumbuhan dari organisme laut yang hidupnya menempel pada material terendam oleh air laut. Biofouling secara umum terbagi menjadi dua berdasarkan ukurannya antara lain; mikrofauling yaitu penempelan organisme yang berukuran kecil seperti bakteri dan alga, sedangkan makrofauling yaitu penempelan organisme yang ukuranya lebih besar seperti teritip, remis, dan cacing polychaeta. Biofouling tumbuh dan berkembang dengan cepat pada berbagai kontruksi buatan manusia yang terendam air. Akumulasi biofouling yang terjadi secara berkelanjutan dapat menimbulkan masalah baik secara ekonomis dan operasional khususnya pada bidang transpotrasi laut.

Pada bidang transportasi laut penumpukan biofouling sering terjadi pada moda transportasi laut yaitu kapal laut, hal in 
dapat menyebabkan kecepatan kapal berkurang hingga $40 \%$ sehingga konsumsi bahan bakar meningkat sampai dengan $30 \%$. Berkurangnya kecepatan kapal mengakibatkan tertundanya waktu berlayar. Selain itu peningkatan konsumsi bahan bakar juga mempengaruhi tingkat emisi gas karbon yang menyebabkan peningkatan suhu pada permukaan bumi, artinya kegiatan yang dilakukan adalah pemborosan dan tidak ramah lingkungan. Menurut Demirel et al., (2013) konsumsi bahan bakar yang dibutuhkan pada transportasi laut di perkirakan sekitar 300 juta ton per tahun dan masih meningkat sebesar 32\%-72\% hingga tahun 2020, dengan adanya penggunaan cat antibiofouling dapat menghemat kebutuhan bahan bakar sebesar 60 milyar US Dollar per tahun dan mengurangi 3,6 juta ton emisi gas sulfur dioksida.

Penumpukan biofouling jika tidak segera diatasi akan menimbulkan dampak yang lebih besar lagi seperti; ganguan pada olah gerak kapal, korosi, dan tumbuhnya strain bakteri yang dapat merusak besi. Berbagai upaya pencegahan untuk menghambat dan menghilangkan biofouling terus dilakukan pengembanganya. Salah satu cara yang umum digunakan oleh masyarakat yaitu menggunakan cat pelindung antifoulan komersial yang komponen utamanya adalah logam berat seperti, TBT (tri-n-butyl tin). Namun saat ini telah dilakukan penelitian yang membuktikan bahwa senyawa TBT tidak hanya toksik terhadap biota biofouling akan tetapi juga membahayakan berbagai organisme lainnya. Oleh karenanya, untuk mencegah terjadinya gangguan atau kerusakan yang lebih besar terhadap lingkungan hidup di laut, beberapa negara maju telah melarang penggunaan cat yang mengandung senyawa TBT ini untuk kapal dan instalasi marikultur (Sudaryanto, 2001).

Hal ini menjadi suatu tantangan baru untuk produsen mantel dalam mengembangkan teknologi alternatif agar dapat mencegah pencemaran pada dasar atau lambung kapal. Berdasarkan hal-hal tersebut diatas maka perlu dicari senyawa alternatif yang bersifat ramah lingkungan sehingga tidak menyebabkan gangguan dan kerusakan terhadap organisme non-target dan kondisi lingkungan di laut. Salah satu senyawa alternatif yang dapat digunakan adalah ekstrak larutan kulit mangrove.

Larutan ekstrak kulit mangrove mengandung senyawa metabolit sekunder Fenolat, Terpenoid, Alkaloid, Saponin, dan Tanin. Senyawa tersebut dapat bersifat toksik pada jumlah konsentrasi yang cukup besar terutama bagi hewan-hewan berdarah dingin seperti ikan, kerang-kerangan, moluska, dan beberapa hewan air lainnya, selain itu senyawa tanin juga dapat berfungsi sebagai mantel pelindung. Syahputra (2010) Menyatakan Ekstrak larutan tanin yang berasal dari kulit mangrove dapat menghambat korosi pada logam, dimana dalam hal ini akumulasi biofoulan juga dapat menyebabkan korosi.

Berdasarkan fakta-fakta yang telah dikemukakan, maka perlu dilakukan penelitian lebih lanjut mengenai pengaruh penambahan ekstrak larutan kulit mangrove pada cat minyak sebagai antifouling sebagai alternatif penggunaan senyawa TBT dan TPT agar lebih ramah terhadap lingkungan di laut.

\section{Bahan dan metode}

\subsection{Waktu dan tempat}

Penelitian ini telah dilaksanakan pada bulan Mei September 2018 bertempat di Laboratorium Fakultas Perikanan Universitas Abulyatama, Laboratorium Kimia Laut Universitas Syiah Kuala dan Kolam Pelabuhan Perikanan Samudera Lampulo Aceh.

\subsection{Alat dan bahan}

Bahan-bahan yang digunakan dalam penelitian ini adalah ekstrak kulit mangrove, cat minyak, ethanol, $\mathrm{HCL}$, sodium hidroksida, klorofom, metanol, asam sulfat, asam klorida, aquadest, kertas saring, amil alcohol, besi (III) klorida, Zn, ammonium hidroksida, pereaksi dragendrof, pereaksi hanger, perekasi wanger, pereaksi mayer, pereaksi lieberman. Peralatan yang digunakan adalah rotary evaporator, plat besi $15 \times 15$, timbangan, baskom, kuas cat, toples besar, sodet kayu, kompor gas, kayu, paku, dan palu

\subsection{Prosedur penelitian}

Penelitian ini menggunakan metode eksperimental lapang, yaitu metode dimana untuk memperoleh data dilakukan percobaan dan pengujian di lapangan. Pengumpulan data dilakukan dengan cara pengamatan pada material uji yang telah direndam pada air laut selama 14 minggu, kemudian dihitung dan dicatat jumlah dan jenis Biofouling yang menempel pada material uji. Material pengujian merupakan lepengan besi ber ukuran $15 \times 15 \mathrm{~cm}$ yang telah di cat dengan menggunakan campuran cat minyak ditambahkan ekstrak larutan kulit mangrove dengan konsentrasi perbandingan 1:1 berjumlah 4 lembar, kemudian dibandingkan dengan 4 lembar lempengan besi yang di cat menggunakan cat minyak tanpa campuran.

\subsection{Analisis data}

Perbandingan material pengujian antara lempengan besi dilakukan dengan menggunakan uji Independent T sampel untuk melihat perbedaan antara lepeng cat minyak yang dicampur dengan ekstrak larutan mangrove dengan cat minyak tampa campuran.

\section{Hasil dan pembahasan}

\subsection{Hasil}

\subsubsection{Pengamatan penempelan biofouling pada material uji}

Hasil penelitian menunjukan adanya perbedaan jumlah biofouling yang menempel pada material uji tersaji pada Gambar 1 dibawah ini.

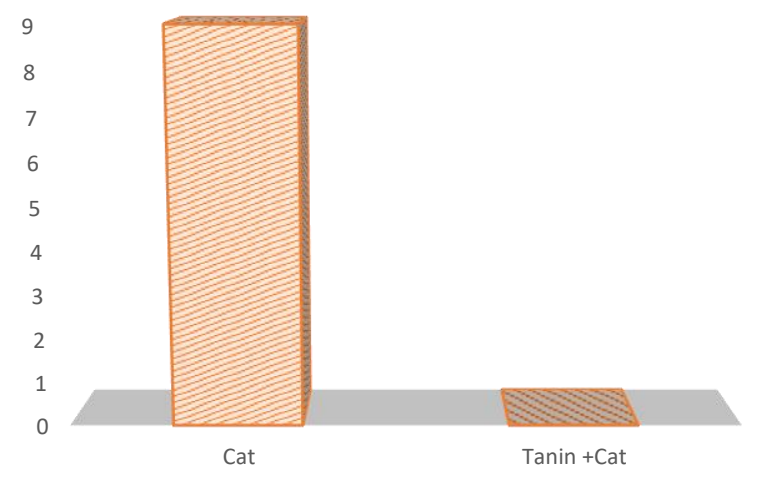

Gambar 1. Jumlah biofouling yang menempel pada material uji.

Hasil pengujian lapangan terlihat ada 9 individu teritip menempel pada 4 lempeng besi yang digunakan sebagai kontrol, dimana jumlah teritip yang menempel pada lempeng satu sebanyak 2 individu, lempeng dua sebanyak 3 individu, lempeng 
tiga sebanyak 1 individu, dan pada lempeng empat sebanyak 3 individu. Sedangkan pada 4 lempengan besi yang di berikan campuran tannin tidak terlihat adanya penempelan biofouling.

\subsubsection{Uji independent-t sampel}

Berdasarkan uji statistik dengan uji Independent Sampel $T$ test diperoleh hasil perbandingan antara material uji sebagai kontrol dan material uji eksperimen, dengan nilai $P$ value one tail sebesar 0,012448082 dan $P$ value two tail sebesar 0,024896163 (Gambar 2). Hal ini menunjukan bahwa nilai $P$ value one tail dan two tail $<0,05$, artinya ada perbedaan nyata antara sampel $u j i$ kontrol dan sampel uji eksperimen.

Tabel 2

Uji t-test: two-sample assuming equal variances.

\begin{tabular}{lcc}
\hline Parameter & 2 & 0 \\
\hline Mean & 2,333333333 & 0 \\
Variance & 1,333333333 & 0 \\
Observations & 3 & 3 \\
Pooled Variance & 0,666666667 & \\
Hypothesized Mean Difference & 0 & \\
df & 4 & \\
t Stat & 3,5 & \\
$P(T<=t)$ one-tail & 0,012448082 & \\
t Critical one-tail & 2,131846786 & \\
$P(T<=t)$ two-tail & 0,024896163 & \\
t Critical two-tail & 2,776445105 & \\
\hline
\end{tabular}

\subsubsection{Hasil uji fitokimia ekstrak kulit mangrove}

Hasil Pengujian fitokimia dari sample ekstrak kulit mangrove dapat dilihat pada tabel dibawah 3 ini.

Tabel 3

Uji fitokimia larutan ekstrak kulit mangrove Rhizopora apiculata.

\begin{tabular}{lcc}
\hline \multicolumn{1}{c}{ Jenis senyawa } & Pereaksi & Konstituent \\
\hline Alkaloid & Dragendroff & + \\
Fenol & Besi (III) klorida & +++ \\
Glikosida & Uji buih & - \\
Lignin & Pereaksi basa & - \\
Peptida & Ninhidrin & + \\
Poliketida & Pereaksi basa & - \\
Steroid & Salkowski & - \\
Tanin & Gelatin & +++ \\
Terpenoid & Lieberman-Buchard & - \\
\hline
\end{tabular}

Berdasarkan hasil pengujian fitokimia terdapat dua senyawa metabolit sekunder yang memiliki jumlah konstituent yang dominan antaralain adalah Fenol dan tanin. Senyawa metabolit sekunder lain yang memiliki jumlah cukup besar adalah dan peptide.

\subsubsection{Identifikasi jenis biofouling yang menempel pada material uji}

Hasil pengamatan di lapangan menunjukan ada dua Jenis biofouling yang menempel pada material uji. Jenis biofouling yang menempel pada material uji tersaji pada tabel 2 dibawah ini.

\section{Tabel 2}

Jenis biofouling yang menempel pada material uji.

\begin{tabular}{lc}
\hline \multicolumn{1}{c}{ Spesies } & Individu \\
\hline Balanus amphitrite & 7 \\
Chthamalus sp. & 2 \\
\hline Total & 9 \\
\hline
\end{tabular}

Berdasarkan hasil pengamatan material uji terdapat 9 individu dari dua spesies berbeda yang menempel pada lempeng pengujian, sembilan individu tersebut terdiri dari; 7 individu Balanus amphitrite dan 2 individu Chthamalus sp.

\subsection{Pembahasan}

Penempelan biofouling pada lempengan besi terjadi menjadi 4 fase pertama yaitu fase oksidasi dan reduksi dimana pada fase ini terjadi pelepasan ion $\mathrm{Fe}^{+2}$ pada lempengan besi kemudian di reduksi oleh $\mathrm{O}^{2}$ yang terdapat di lingkungan. Fase kedua adalah fase penempelan microorganisme pada lempengan setelah terjadi proses oksidasi dan reduksi. Fase ke tiga microorganisme bergabung membentuk suatu koloni yang di selubungi oleh senyawa polimer ekstraselular. Fase ke empat merupakan fase dimana biofouling tumbuh dan berkembang secara massive.

Menurut Chambers et al. (2006) proses pertumbuhan biofouling terjadi melalui empat fase; fase pertama adalah terdegradasinya lapisan terluar pada besi disertai dengan penyerapan bahan organic yang menempel di lapisan besi oleh microfouling, fase kedua penempelan microorganisme secara berkala secara terus-menerus sehingga terbentuk menjadi larva dan spora ,fase ke tiga pembentukan koloni yang diselimuti oleh senyawa polimer, fase ke empat yaitu perkembangan menjadi macrobiofouling dan tumbuh secara besar. Sedangkan menurut Costerton (1999) Penempelan mikroorganisme merupakan awal dari pembentukan mikrofouling dan makrofouling yang dipengaruhi oleh sifat-sifat fisika dan kimia dari permukaan seperti tekstur, hydrophobicity, dan sifat biologi bakteri seperti pergerakan (swarning) struktur (pili) dan produksi molekul penempel (ekstraselular polisakarida).

Hasil penelitian menunjukan adanya pengaruh penambahan ekstrak kulit mangrove pada cat terhadap jumlah penempelan biofouling yang tumbuh pada material lempeng besi yang di uji lapangan, berdasarkan hasil pengamatan penambahan ekstrak kulit mangrove dapat mengurangi pertumbuhan biofouling. Hasil pengujian statistik juga menunjukan bahwa penambahan ekstrak kulit mangrove ke dalam cat berpengaruh secara nyata, dimana dapat dilihat hasil pengujian statistik nilai $P$ value pada uji Independent $T$ test lebih kecil daripada 0,05 (Tabel 2).

Penurunan jumlah penempelan biofouling pada material uji diduga disebabkan oleh kandungan senyawa metabolit sekunder yang terdapat dalam kulit mangrove, dimana senyawa metabolit sekunder yang terdapat pada kulit mangrove antara lain; Tanin, Alkaloid, Fenol, dan Peptida. Hal ini dapat dilihat pada (Tabel 3). Dari keempat senyawa metabolit sekunder tersebut, diduga senyawa Tanin, Alkaloid dan Fenol merupakan senyawa yang paling berpengaruh terhadap penempelan biofouling. Tanin merupakan senyawa polifenol yang terdapat pada tumbuhan terutama pada bagian kulit tumbuhan. Menurut Carter et al. (1978) Tanin merupakan polifenol alami yang terdapat pada bagian kulit kayu, dan banyak mengandung fenol yang memiliki gugus $\mathrm{OH}$.

Tanin merupakan Senyawa yang biasa digunakan sebagai pewarna dan juga penyamak jaring ikan, sifat tanin yang memiliki daya rekat tinggi juga dapat dimanfaatkan sebagai campuran lem. Senyawa tanin memiliki gugus $\mathrm{OH}$ yang dapat mereduksi proses reaksi oksidasi dan reduksi sehingga memiliki kemampuan untuk menghambat terjadinya pelepasan ion $\mathrm{Fe}^{+2}$ yang menyebabkan korosi dan penempelan biota fouling pada lapisan permukaan lempengan logam besi. Menurut Hangerman, (2002) Tanin banyak dikonsumsi oleh manusia atau hewan yang dapat mempengaruhi pemanfaatan protein dengan membentuk protein yang terlarut, antioksidan, dan pemanfaatan dalam pencegahan reaksi-oksidasi pada logam. Menurut Chambers et al. (2006) Senyawa alami Tanin Quebracho yang dikombinasikan 
dengan cat dapat menurunkan kandungan tembaga jika dibandingkan dengan cat biasa. Sedangkan Syahputra (2010) Menyatakan Ekstrak larutan tanin yang berasal dari kulit mangrove dapat menghambat korosi pada logam, dimana dalam hal ini akumulasi biofoulan juga dapat menyebabkan korosi.

Senyawa alkaloid dan fenol juga dapat mengurangi jumlah penempelan biofouling karena kedua senyawa tersebut bersifat racun yang dapat membunuh biofouling. Alkaloid merupakan senyawa organic yang umumnya terdapat pada tumbuhan, senyawa ini bersifat basa dan memiliki gugus atom Hidrogen yang cukup banyak. Gugus atom hidrogen pada alkaloid dapat menyebabkan efek anastesi bahkan kematian pada hewan tergantung dari jumlah dosis yang diberikan. Menurut Arlyza, (2007) bahwa senyawa metabolit sekunder alkaloid yang dikeluarkan oleh Acidian dapat mengurangi pertumbuhan biofouling khususnya teritip. Senyawa fenol atau asam fenolat merupakan senyawa memiliki tingkat keasaman yang lebih tinggi daripada alkohol dan fenol bisa menyebabkan pembakaran kimia pada kulit, tingkat keasaaman yang tinggi pada fenol dapat menyebabkan kematian pada biofouling. menurut Suryati et al. (1999) senyawa turunan terpenoid dan asam fenolat dapat bersifat toksik pada biofouling jenis kerangkerangan.

Penempelan biofouling pada material uji terdapat dua jenis spesies antara lain adalah Blanus amphirite sebanyak 7 individu sedangkan jenis spesies Chthamalus sp. 2 individu, berdasarkan hasil pengamatan jenis Blanus Amphirite lebih banyak ditemukan pada material uji dibandingkan dengan jenis Chthamalus sp.. Hal ini diduga karena wilayah penempatan sampel yang dekat dengan dermaga pelabuhan sehingga jenis tersebut lebih mendominansi. Teritip spesies Blanus amphirite merupakan teritip yang tumbuh di wilayah dengan tingkat pencemaran logam pada perairan tinggi. Sedangkan Jenis Chthamalus $\mathrm{sp}$ adalah jenis teritip yang banyak terdapat pada batu karang yang berada di sekitar pantai.

\section{Kesimpulan}

Berdasarkan hasil penelitian dan analisis terhadap penambahan ekstrak kulit mangrove pada cat minyak sebagai antifouling, maka dapat disimpulkan sebagai berikut;

1. Biofouling terjadi menjadi 4 fase yaitu; oksidasi dan reduksi ion $\mathrm{Fe}^{+2}$, penempelan mikrooorganisme, pembentukan koloni, dan perkembangan biofouling.

2. Penambahan Eksrak kulit mangrove dalam cat mampu menghambat dan mengurangi jumlah penempelan biofouling secara nyata pada material uji.

3. Tanin hasil ekstrak mampu melapisi lempengan besi dan mengurangi proses oksidasi dan reduksi sehingga dapat menghambat proses korosi juga penempelan biofouling.

\section{Bibliografi}

Arlyza, I.S., 2007. Bahan Aktif Dari Organisme Laut Sebagai Pengendali Biota Penempel. Pusat Penelitian Oseanografi-LIPI. Jakarta. Jurnal Oseana, 32(1). ISSN 0216-1877.

Chambers, L.D., Stokes, K.R., Walsh, F.C. Wood, R.J.K., 2013. Modern approaches to marine antifouling coating. Jurnal Surface and Coatings Technology 201 (2006) 3642-3652.

Costerton, J.W., 1999. Antifouling. Center for Biofilm Engeneering. Montana State University.
Carter, F. L., A. M. Carlo and J. B Stanley, 1978. Termiticidal Components of Wood Extracts Methyljuglone from Diospyros Virginia. Journal Agriculture. 26(4):869-873.

Bozeman, M.T., Demirel, Y.K., Khorasanci, M., Turan, O., Incecik, A., 2013. On the importance of antifouling coating regrading ship resistance and powering. Low carbon shiping conference. Departement Of Naval Architecture And Marine Engineering, University Of Strathclyde, 100 Montrose Street, Glasgow G4olz, United Kingdom.

Hagerman, E., 2002. Tannin Chemistry. Department of Chemistry and Biochemistry, Miamy University, Oxford.

Sudaryanto, A., 2001. Pencemaran Laut Oleh Senyawa Organotin. Indonesia Institute Of Science (LIPI). Jurnal Teknologi lingkungan Vol. 2 No. 3 ISSN P-1411-318X.

Suryati, E., Parenrengi, A., Rosmiati., dan Laining, A., 1999. Penapisan dan Analisis Sponge Efektif Sebagai Antibiofouling di Tambak Dan Keramba Jaring Apung. Balai Penelitian Perikanan Pantai Maros Sulawesi Selatan. Jurnal Marina Chimica Acta hal 16 - 20. ISSN 1411- Edisi Spesial.

Syahputra, F., 2010. Pengaruh Cat yang ditambahkan Tanin Mangrove Terhadap Korosi Logam. Skripsi. Universitas Syiah Kuala. Banda Aceh (Tidak dipublikasikan) 